\title{
Los usos del pasado durante la última dictadura militar. El Holocausto como horizonte de identificación, distanciamiento y negociación de los actores de la comunidad judía en tiempos de régimen militar
}

\section{O uso do passado durante a última ditadura militar. Holocausto como horizonte de identificação, distância e negociação dos atores da comunidade judaica em tempos de regime militar}

\author{
Emmanuel Nicolás Kahan \\ Investigador y académico \\ Instituto de Investigaciones en Humanidades y Ciencias Sociales \\ Universidad Nacional de La Plata/CONICET \\ Argentina \\ Laura Schenquer \\ Investigadora y académica \\ Instituto de Humanidades y Ciencias Sociales del Litoral / CONICET \\ Argentina \\ Recibido: 4/5/2016 - Aceptado: 27/7/2016 \\ DOI: http://dx.doi.org/10.15359/tdn a.32-60.8
}

\section{Resumen}

Vivimos en una era en la que el Holocausto se ha convertido en un tropo universal del trauma histórico.

El genocidio nazi adquirió

el carácter del mayor

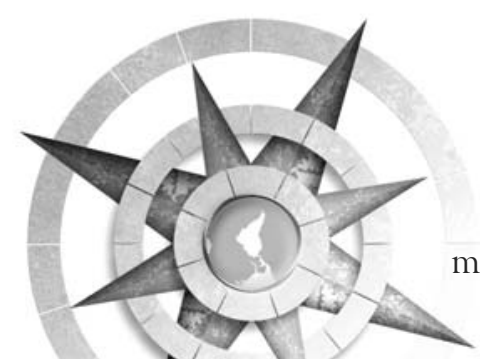

quiebre civilizatorio, por lo que su mera mención y comparación con otros acontecimientos represivos permite activar o bloquear sentidos sobre acontecimientos específicos. En el caso argentino, las resonancias de la memoria del Holocausto penetraron en los orígenes mismos de la última dictadura militar. Tan pronto como en 1976 fueron visibles y públicas las voces que, desde el exterior del país, denunciaban al régimen por perpetrar un genocidio. Este artículo propone analizar algunos usos del Holocausto durante la dictadura militar en Argentina problematizando los modos en los 
que la memoria del Holocausto activó o bloqueó sentidos e imaginarios sobre las prácticas del régimen represivo.

Palabras claves: Holocausto, dictaduras latinoamericanas, régimen militar en $\mathrm{Ar}$ gentina, judíos, Jacobo Timerman, memoria y pasado, historiografía argentina

\section{Resumo}

Vivemos em uma era em que o Holocausto tornou-se um tropo universal de trauma histórico. O genocídio nazista adquiriu o caráter da maior quebra civilizatório. Sua mera menção e comparação com outros eventos repressivos, permite ativar ou bloquear sentidos sobre eventos específicos. Na Argentina, as ressonâncias de memória do Holocausto penetraram as próprias origens da última ditadura militar. Já em 1976 as vozes de fora do país denunciando o regime de perpetrar genocídio, foram visível e público. Este artigo tem por objetivo analisar alguns usos do Holocausto durante a ditadura militar na Argentina, problematizando as formas pelas quais a memória do Holocausto ativo ou bloqueou sentidos e imaginários sobre as práticas do regime repressivo.

Palavras chave: Holocausto, ditaduras latino-americanas, regime militar na Argentina, judeus, Jacobo Timerman, memória e pasado, historiografia argentina

\section{Introducción}

Según Andreas Huyssen (2007: 17) vivimos en una era en la que el Holocausto se ha convertido en un «tropos universal del trauma histórico». El genocidio nazi adquirió el carácter del mayor quiebre civilizatorio, por lo que su mera mención y comparación con otros acontecimientos represivos (como las dictaduras del Cono Sur, los genocidios en Ruanda, Bosnia, etc.) permite activar o bloquear sentidos en cada historia específica.

En el caso argentino, las resonancias de la memoria del Holocausto penetraron en los orígenes mismos de la última dictadura militar. Tan pronto como en 1976 fueron visibles y públicas las voces que, desde el exterior del país, denunciaban al régimen por perpetrar un genocidio. De hecho, tal como señala Kahan (2014), dicha denuncia antecedió al reclamo sobre personas detenidas-desaparecidas interpuesta por los organismos de derechos humanos.

Este artículo propone analizar tres usos del Holocausto durante la dictadura. Siguiendo la propuesta de Huyssen, trazaremos un recorrido resaltando hechos concretos en los que la memoria del Holocausto activó o bloqueó sentidos e imaginarios sobre las prácticas del régimen represivo. Comenzaremos por analizar un escrito del periodista Jacobo Timerman, previo a su liberación, en el que se reconoce como víctima judía de la dictadura, señalando que en Argentina se estaba

150 Los usos del pasado durante la última dictadura militar... Emmanuel Nicolás Kaban • Laura Schenquer
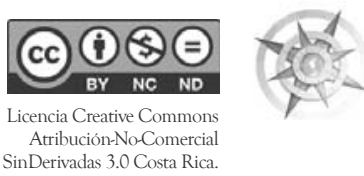
produciendo un «nuevo Holocausto» (Elie Wiesel. Direct translation of suggestions made by Jacobo Timerman on Friday, 20th of July 1979"). Analizaremos cómo esa denuncia fue potenciada por el propio Timerman en 1979 en el marco de la llegada al país del escritor y sobreviviente del Holocausto Elie Wiesel, que a su vez fue desactivada por los principales referentes del campo judío argentino.

El segundo ejemplo que abordaremos es el de la miniserie Holocausto. La transmisión del programa de televisión fue anunciada en el año 1978, no obstante dos años más tarde aún no había sido emitida y los medios de comunicación especulaban con que la censura impedía su presentación. Este caso permitirá reconocer cómo el Holocausto permitió reclamar por la televisación de la miniserie haciendo públicos y visibles los mecanismos autoritarios y represivos del régimen militar.

Finalmente, analizaremos cómo durante los primeros tramos de la democracia en Argentina el tópico del Holocausto se volvió a erigir como un horizonte de homologación de la propia experiencia que llegó a enfrentar a quienes se habían constituido como detractores del régimen dictatorial durante sus últimos años: Herman Schiller y Marshall Meyer.

\section{Del «nuevo» al "mini-Holocausto» argentino}

Jacobo Timerman, periodista argentino, fue director de varios emprendimientos periodísticos exitosos. En 1971 fundó La Opinión, que se convertiría en uno de los principales medios de comunicación del país hasta que fuera intervenido por las autoridades de la última dictadura, al mismo tiempo que él fue secuestrado. Su detención, realizada el 15 de abril de 1977, fue el resultado de una crisis que maduró durante varios meses. El problema radicaba en las fuentes de financiamiento del periódico. David Graiver era uno de los principales accionistas y las autoridades militares sostenían que este era quien administraba los fondos de la organización político-militar Montoneros. ${ }^{1}$

1 Las Fuerzas Armadas pretendian que Timerman les entregara los fondos con los que había financiado La Opinión, proporcionados por Graiver, el supuesto banquero de Montoneros. Eran los fondos que Montoneros había recibido del pago del rescate del secuestro de los hermanos Born. Sobre el caso véanse los trabajos de Marcelo Borrelli (2011). Una «batalla ganada»: Clarín y la compra de Papel Prensa (1976-1978), en Saborido, J. y Borrelli, M. (Comp.), Voces y Silencios. La prensa argentina y la dictadura militar (1976-1983) (pp. 19-53). Buenos Aires: Editorial Eudeba; Raanan

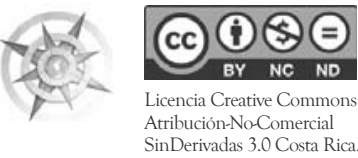

Los usos del pasado durante la última dictadura militar... 151 Emmanuel Nicolás Kaban • Laura Schenquer 
La prensa argentina visibilizó la detención de Timerman a través de la publicación del comunicado distribuido por el Comando de Zona I. Durante varias semanas La Nación y Clarín alimentaron a la opinión pública con notas sobre el caso Graiver referidas a las conexiones entre el grupo financiero, las organizaciones "subversivas» e incluso el ex ministro de economía José Ber Gelbard. ${ }^{2}$ Mientras revistas nacionalistas - como Cabildo- señalaban que el caso se trataba de la mayor conspiración judeo-marxista de la

Rein (2011). iJudios-argentinos o argentinos-judios? Identidad, Etnicidad y diáspora. Buenos Aires: Editorial Lumiere; Juan Gasparini (2007). David Graiver. El Banquero de los Montoneros. Buenos Aires: Grupo Editorial Norma y de Graciela Mochkofsky (2003). Timerman. El periodista que quiso ser parte del poder (1923-1999). Buenos Aires: Editorial Sudamericana.

2 Los medios de comunicación señalaban las conexiones entre el grupo financiero y el ministro de Perón que había presionado al Grupo Civita para que vendiese las acciones de la empresa Papel Prensa a David Graiver Jorge Saborido, 2004. El antisemitismo en la Historia argentina reciente: la revista Cabildo y la conspiración judía. Revista Complutense de Historia de América, 30, [pp. 209-223]; Daniel Cecchini y Jorge Mancinelli, (2010). Silencio por Sangre. La verdadera historia de Papel Prensa. Buenos Aires: Editorial Miradas al Sur, pp. 45-48. historia Argentina (Saborido, 2004), en la revista Carta Política, dirigida por Mariano Grondona, una nota sin firma indicaba que el caso Graiver evidenciaba que el «problema judío no había sido resuelto en Argentina» (Carta Política, junio, 1977: 12). Por su parte, la prensa judía reflejó la tergiversación de las acusaciones que eran miradas con preocupación por la dirigencia del colectivo judío.

El caso Graiver y la detención de Timerman coincidieron con un acercamiento del discurso de la Delegación de Asociaciones Israelitas Argentinas (DAIA) al régimen militar, que incluyó el apoyo a la «lucha antisubversiva». A un mes del secuestro, en mayo de 1977, la entidad judía abandonó su tradicional postura de "prescindencia» o neutralidad política (no alineación a ningún Gobierno) y comenzó a adherirse a las proclamas militares que reivindicaban actuar en pos del restablecimiento del orden. El presidente de la DAIA, Nehemías Resnizky destacó, en el marco de las acusaciones vertidas sobre la comunidad judía tras el caso Graiver, que «la subversión y la corrupción, en cuanto enemigos del país, son también de la comunidad judía» (Informativo DAIA, No. 92, 5 de junio, 1977, pp. 16-17). El discurso de Resnizky fue pronunciado en una reunión de la Comisión Directiva de la DAIA. Más tarde, otros dirigentes de

152 Los usos del pasado durante la última dictadura militar... Emmanuel Nicolás Kaban - Laura Schenquer
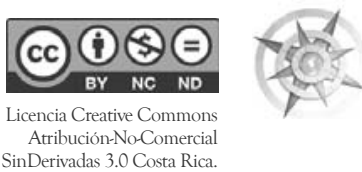
la DAIA, Juan Gurevich, Marcos Korenhendler, Ricardo Gordon y Naúm Barbarás, le solicitaron una reunión al ministro del Interior, Albano Harguindeguy, en la que expresaron con convicción esperar los resultados de la investigación a cargo del Gobierno sobre el caso Graiver. «Deseamos como el que más el esclarecimiento de los hechos y el castigo de los culpables sean o no judíos» (Informativo DAIA, N. ${ }^{\circ}$ 92, 5 de junio de 1977, p. 6) $)^{3}$.

Posiblemente el abandono de la neutralidad se vinculaba al clima social y político que atravesaba el país. La DAIA logró a través de su posicionamiento mantener el diálogo con los funcionarios del régimen, que hacían lugar a los pedidos de la dirigencia judía. ${ }^{4}$ Aunque este alineamiento no

3 Para un análisis pormenorizado de las diferentes etapas que atravesó la relación de la DAIA con las autoridades militares véase la tesis doctoral de Laura Schenquer (2012). Actitudes sociales en dictadura: estudio sobre las dirigencias de DAIA y de las instituciones religiosas liberales durante el último régimen militar (1976-1983). Manuscrito inédito. Tesis de Doctorado en Ciencias Sociales. Universidad de Buenos Aires.

4 Como por ejemplo, el Gobierno accedió al pedido de la DAIA y ordenó el cierre de las editoriales Milicia y Odal, que publicaban literatura antisemita. En el llamado Archivo BANADE se encuentra un informe de inteligencia le impidió a Resnizky cuestionar la arbitrariedad con la que había sido detenido Jacobo Timerman. En 1977, por ejemplo, declaró, en respuesta a las preguntas que en Washington le realizaron miembros del Congreso Judío Mundial, que «la comunidad judeo-argentina está hondamente preocupada por el continuado y no explicado encarcelamiento de Jacobo Timerman» (Nueva Presencia, 10 de diciembre, 1977, p. 1).

Existen controversias acerca del rol que mantuvo la DAIA en este período. Algunos señalan que se comportó como una entidad intimidada - en particular tras el secuestro del hijo del presidente de la DAIA-, mientras que otros discuten esta imputación y alegan como evidencia la serie de discursos en los

de la SIP (Secretaría de Información Pública) que muestra el curso de las solicitudes de la DAIA al Gobierno. La SIP analiza el fascículo n. ${ }^{\circ} 3$ "iQué es el judaísmo?» de la Biblioteca Imperialismo, Comunismo y Judaísmo, y llega a la conclusión de que "constituye un ataque contra la colectividad judía que podría conducir a reacciones violentas aprovechables por la subversión» (Memorandum N. ${ }^{\circ} 51$ producido por la Dirección de Inteligencia, 9 de agosto de 1976. Carpeta 4. Páginas 446-453. Archivo BANADE, CONADEP).

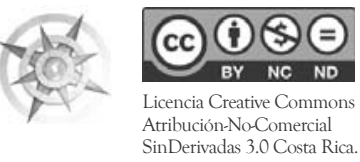

Los usos del pasado durante la última dictadura militar... 153 Emmanuel Nicolás Kaban • Laura Schenquer 
que Resnizky denunció y solicitó la liberación del director de La Opinión. ${ }^{5}$

5 Según las madres de Plaza de Mayo Reneé Epelbaum y Frida Rosenthal, el secuestro del hijo del presidente de la DAIA coincidió con el momento en que la DAIA dejó de recibirlas. Para una serie de investigadores ese hecho marca la cooptación e intimidación de la entidad judía. Véase Ignacio Klich (1986). Política comunitaria durante las juntas militares argentinas: la DAIA durante el proceso de reorganización nacional. En Senkman, L. (Comp.), El antisemitismo en Argentina, (pp- 274-309). Buenos Aires: CEAL; Margarite Feitlowitz (1998). A Lexicon of terror: Argentina and the legacy of torture. (pp. 101-107) Oxford: Oxford University; Gabriela Lotersztain (2008). Los judios bajo el terror. Argentina 1976-1983, (p. 30). Buenos Aires: Editorial Ejercitar la Memoria y Paul Katz (november, 2011). A New 'Normal': Political Complicity, Exclusionary Violence and the Delegation of Argentine Jewish Associations during the Argentine Dirty War. The International Journal of Transitional Justice, 5(3) [pp. 366-389]. Por su parte, entre los que defendieron en esos años el posicionamiento de la DAIA, y que especialmente señalaron que la entidad peticionó incesantemente la liberación de Timerman, se encuentran: el director de Nueva Presencia Herman Schiller, el rabino Roberto Graetz, miembro de la Asamblea Permanente por los Derechos Humanos (APDH)
En agosto de 1979, un mes antes de la llegada de la Comisión Interamericana de Derechos Humanos (Organización de Estados Americanos, OEA) y de la liberación de Timerman, se confirmó la presencia en Buenos Aires del escritor y sobreviviente de Auschwitz, Elie Wiesel, por entonces a cargo del proyecto del Museo del Holocausto en Washington, impulsado por el Gobierno de Carter.

La visita de Wiesel fue autorizada por la Junta Militar, que extendió la visa de ingreso al país. ${ }^{6}$ En ese y otros detalles había estado trabajando el rabino norteamericano Marshall Meyer, rector del Seminario Rabínico Latinoamericano. La invitación, recordó su esposa Naomi Meyer, fue cursada con una intencionalidad política cla-

y el periodista Moshé Wainstein. Al respecto ver Wainstein (27 de noviembre, 1981). Detenidos-Desaparecidos: un nuevo hito en la ardorosa polémica interna desatada en la comunidad judía. Nueva Presencia. Pp. 10-11 y 18; el testimonio de Graetz en el Informe Especial sobre detenidos y desaparecidos judios. 1976-1983. (Enero, 1984). DAIA. (Archivo CES-DAIA); y la carta de M. Wainstein al director de $\mathrm{La}$ Razón Patricio Peralta Ramos (9 de noviembre, 1984). Archivo personal de N. Resnizky.

6 Telegrama de Adolfo Smolarz al rabino Marshall T. Meyer (1 de agosto, 1979). Archivo SRL, Telegrama.
154 Los usos del pasado durante la última dictadura militar... Emmanuel Nicolás Kaban • Laura Schenquer

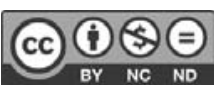

Licencia Creative Commons Atribución-No-Comercial SinDerivadas 3.0 Costa Rica.

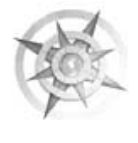


ra: «Marshall trajo a Elie Wiesel a la Argentina para presionar al gobierno y lograr que dejen libre a Jacobo. La idea era tratar de movilizar al mundo, a través de la difusión del caso en la prensa internacional» (Entrevista a Naomi Meyer realizada por Gabriela Lotersztain, DVD 1, no 1 , s/f.e. [1996-2006], IDES.) Jacobo Timerman también pensaba que esta visita lograría visibilizar su encarcelamiento en el marco de un proceso de hostigamiento a los judíos de Argentina:

Antes que nada, debemos tener una idea clara de quién es Elie Wiesel y lo que él significa para el pueblo judío que él simboliza. Si en momentos tan cruciales de la historia de la comunidad judía en la Argentina, este símbolo llega al país, sólo puede venir en función de lo que simboliza: descubrir cuáles son los males que aquejan a la comunidad judía argentina (...) No podemos derrotar el antisemitismo, pero tenemos que intentar que no nos destruya ("Elie Wiesel. Direct translation of suggestions made by Jacobo Timerman on Friday, 20th of July 1979". Archivo SRL, 20/07/79, Colección Marshall Meyer. Caja 2.).

Este documento adelantaría lo que luego sería el argumento principal de su libro Preso sin nombre, celda sin número. ${ }^{7}$ Allí, a través del testimonio de su cautiverio, se enfatizaba el carácter antisemita de la maquinaria de represión dispuesta por el régimen militar argentino. Bajo este encuadre, se invisibilizaba que el régimen militar argentino actuaba conforme a la doctrina de seguridad nacional y que la persecución se ejercía sobre el enemigo interno considerado «subversivo». Timerman, en cambio, afirmaba que la represión hostigaba y victimizaba a los judíos, habilitando sentidos de interpretación que pusieran en diálogo la experiencia argentina con el Holocausto:

Nadie nos está llevando a las cámaras de gas. Pero ipuede Elie Wiesel explicar que el antisemitismo comienza por tener raíces solamente, y que sus efectos se pueden producir dentro de muchos años, y que la comunidad judía en Argentina está facilitando que esas raíces se estén fortaleciendo? ¿Puede explicar que hay antisemitismo sin jabón? (Elie Wiesel. Direct translation of suggestions made by Jacobo Timerman on Friday, 20th of July 1979").

El antisemitismo «sin cámaras de gas, ni jabón» remitía a una caracterización de la represión local y a sus

7 Publicado en 1981 en inglés y traducido al español en 1982. (Rein, 2011:218)

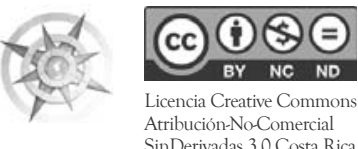

Los usos del pasado durante la última dictadura militar... 155 Emmanuel Nicolás Kaban • Laura Schenquer 
métodos como copias no-fieles de las empleadas por los nazis en Europa. Al trazar puentes con el tropo de la barbarie nazi Timerman pretendía sensibilizar a la opinión pública internacional para que esta, a su vez, presionase al régimen militar, socavando su imagen celosamente custodiada a nivel oficial. La denuncia del carácter genocida/antisemita de la dictadura argentina no tuvo receptores, al menos no a nivel local ni a nivel público, en oposición a lo que ocurría en el exterior, donde el rabino Morton Rosenthal y Burton S. Levinson de la Liga Anti-difamatoria de la B'nai Brith radicada en Estados Unidos denunciaban en los mismos términos que Tímerman a la dictadura argentina. ${ }^{8}$

En 1979 la visita de Wiesel fue anunciada por los principales medios de comunicación. Sin embargo, este no estuvo dispuesto a equiparar la situación Argentina con el Holocausto. Wiesel era de los que consideraban que el Holocausto perpetrado por el régimen nazi no podía ser comparado con otros procesos de segregación,

8 Sobre el informe Rosenthal-Levinson presentado el 28 de septiembre de 1976 al Congreso norteamericano véase Schenquer (2012). Actitudes sociales en dictadura: estudio sobre las dirigencias de DAIA y de las instituciones religiosas liberales durante el último régimen militar (1976-1983). Manuscrito inédito. Tesis de Doctorado en Ciencias Sociales, Universidad de Buenos Aires. persecución e incluso exterminio de la población por parte del Estado. ${ }^{9}$

Ante la pregunta de los periodistas sobre la imagen del país en el exterior, Wiesel contestó que en Estados Unidos preocupaba la situación de los derechos humanos y que «todo el mundo, en todas partes, sabe sobre Jacobo Timerman. Espero poder verlo. Yo soy un hombre que trata con cuestiones morales, no políticas. Pero en este caso creo que debemos tocar lo político» (Buenos Aires Herald, 1 de septiembre de 1979, p. 9). A pesar de que Wiesel no pudo ver a Timerman en su prisión domiciliaria, dio cuenta de tener la intención de que se produjera un encuentro y señaló la relevancia que la detención del periodista había adquirido a escala internacional. ${ }^{10}$

La visita de Elie Wiesel y el fallido intento de comparar la situación local

9 Fue con esta intención que Elie Wiesel acuñó el término holocausto, según Agamben en su texto Homo Sacer III. Lo que queda de Auschwitz. El archivo y el testigo (2002). Madrid: Editora Nacional, p. 28.

10 Wiesel al final de su visita, en el Aeropuerto de Ezeiza, señaló que, a pesar de la intervención del embajador norteamericano Castro, las autoridades militares argentinas no le habían permitido ver a Timerman (Buenos Aires Herald, 5 de septiembre de 1979, p. 1).

156 Los usos del pasado durante la última dictadura militar... Emmanuel Nicolás Kaban • Laura Schenquer

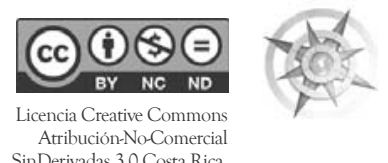


con el Holocausto benefició a la dirigencia judía local. Esta, en más de una oportunidad, había desmentido las denuncias sobre el antisemitismo oficial de la dictadura militar, así como también negaba rumores sobre posibles evacuaciones masivas preparadas por el Estado de Israel para salvar a la población judía de Argentina. ${ }^{11} \mathrm{La}$ entidad judía señaló que desde el exterior «atemorizaban a los judíos» con denuncias infundadas sobre el antisemitismo oficial en Argentina.

Sin embargo, no solo la DAIA se oponía a este tipo de comparaciones que trazaban puentes o conexiones entre el Holocausto y la dictadura argentina. También los rabinos liberales reunidos en el Seminario Rabínico Latinoamericano opinaban de modo similar: consideraban una exageración presentar los hechos locales como un nuevo Holocausto.

Los rabinos Roberto Graetz en Emanu-El y Marshall Meyer en Bet-El (ambas congregaciones en Buenos Aires) denunciaron la situación de Jacobo

$11 \mathrm{Al}$ menos en dos oportunidades los medios de comunicación publicaron las desmentidas de la DAIA acerca de un supuesto plan de evacuación masiva de judíos de Argentina a Brasil (Mundo Israelita, 1 de julio de 1978, p.15; Informativo DAIA, N. ${ }^{\circ} 104$, s/f. e. [08-09/81], p. 2).
Timerman y acompañaron durante su cautiverio cada pedido de liberación. También solían evidenciar hechos de antisemitismo puntuales. No obstante, al ser consultados sobre las dictaduras latinoamericanas y sus rasgos antisemitas, aconsejaban evitar apreciaciones falsas que la prensa internacional «sobreactuaba», difundiendo en un tono morboso y amarillo.

El rabino Meyer, entrevistado por la situación argentina, señaló que «no es cierto lo que algunas personas piensan en EEUU, que aquí se dispara a los judíos en las calles. Tampoco tiene sentido decir que el antisemitismo no es un problema en este país» (The Miami Herald, 3 de julio de 1981, pp. 1 y 14). Y más tarde agregó: «La gente no va por las calles disparando a los judíos. Para la prensa, la asimilación de los judíos es una cuestión menos dramática pero es por lejos la mayor batalla que enfrentan en el país» ( $\mathrm{Ha}$ dassah, febrero de 1983: 7). El dirigente liberal parecía entender que el antisemitismo en Argentina no había alcanzado niveles cruciales como para declararlo una amenaza para la continuidad de la vida judía en este país.

El rabino Graetz, por su parte, hizo declaraciones del mismo tenor en una de sus prédicas habituales en las ceremonias de los días viernes en su congregación. Allí bregaba por el

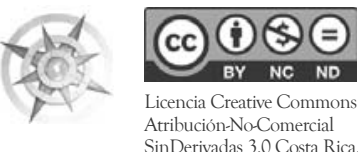

Los usos del pasado durante la última dictadura militar... 157 Emmanuel Nicolás Kaban • Laura Schenquer 
compromiso que se requería para denunciar la desaparición de personas, pero sin referirlo a un problema con vehemencia hacia los judíos:

En una sociedad totalitaria, ¿cuál debe ser la posición del judío ante un régimen que le es genéricamente benévolo [cursivas añadidas], pero que se pasea por encima de miles de ciudadanos? La defensa de la vida y la búsqueda de justicia van íntimamente ligadas (...) Cuando el judío, ante la realidad de un desaparecido, encoge los hombros para tímidamente exclamar «jalgo habrá hecho!», ha vaciado su judaísmo de cualquier contenido ético que justifique la lucha por nuestra continua sobrevivencia (Graetz, 1979, pp. 10-12).

La referencia a los judíos en un lugar de testigos, y no como atributo o motivo de las desapariciones, permite reflexionar sobre quiénes eran las víctimas a las que se refería. Graetz se apartaba de la interpretación de antisemitismo sin jabón, referida por $\mathrm{Ti}$ merman, para calificar a las prácticas represivas de la dictadura argentina.

Sin obviar que el control del régimen pudo haber condicionado acompañar la denuncia de Timerman, habría que considerar otros motivos que inhibieron la presentación del régimen militar en clave de genocidio antijudío. Planteamos considerar que el universo de significados que despertaban las prácticas antisemitas en aquel entonces no eran las que Timerman denunciaba, sino las prácticas "habituales» -tales como atentados, pintadas, amenazas de bombas, etc.-, hechos que solían suceder en un período más largo que el de la dictadura. ${ }^{12}$ Estas prácticas antijudías, que eran denunciadas por los referentes del campo judío, se presentaban disociadas de la violencia represiva desplegada por el Estado.

La miniserie Holocausto: tensiones, debates y consideraciones sobre una experiencia particularmente judía

La serie de televisión Holocausto fue emitida en Estados Unidos en abril de 1978 y constituyó la primera difusión masiva de información sobre el Holocausto transmitida a la opinión pública norteamericana. Reproducida en diversos países, fue vista por millones de personas con un absoluto récord de audiencia. Sin embargo, y pese al flujo informativo que destacaba el éxito de la serie, Argentina no se sumaría a la lista de países que la emitían.

12 Emmanuel Kahan, en su texto Recuerdos que mienten un poco. Vida y memoria de la experiencia judía durante la última dictadura militar (2014), distingue entre antisemitismo en su faz cotidiana o pública frente al antisemitismo en su faz clandestina.

158 Los usos del pasado durante la última dictadura militar... Emmanuel Nicolás Kaban • Laura Schenquer
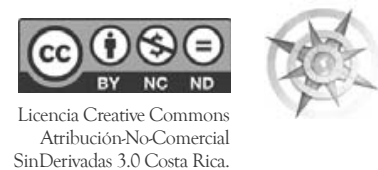
Al respecto, y poco tiempo después de su presentación televisiva, una figura relevante como Carlos Polak -miembro de la agrupación Fraie Schtime, secretario de Cultura de AMIA y en 1984 nombrado juez de la nación por el Gobierno de Alfonsín- se preguntaría desde las páginas de Nueva Presencia "iQuién le teme a [la serie] "Holocausto” en nuestro país?». El artículo sostenía que la serie había podido emitirse en varios países mientras que en Argentina seguía estando prohibida. Si bien se había anunciado su puesta en el aire durante el año 1978, «fuerzas ocultas» habían presionado para impedirlo. Su falta de emisión, sugería Polak, estaba «en relación directa con el avance del antisemitismo en nuestro país» (24 de agosto de 1979: 5).

Más allá de esta percepción, los miramientos para su puesta en el aire estuvieron vinculados a las imágenes e historias que en la serie se narraban ${ }^{13}$ : ¿acaso la censura dictatorial estaría dispuesta, en 1978, a mostrar imágenes de campos de exterminio y sometimiento a condiciones terribles de detención, similares a las descritas por los exiliados argentinos que denunciaban, ese mismo año, al régimen dictatorial por las violaciones sistemáticas

13 En el caso de Chile sucedió algo similar: la televisión compró los derechos de transmisión en 1980. Fue emitida en 1990 con la llegada de la democracia. a los derechos humanos? ¿O debiera pensarse que, ante la dificultad de establecer puentes entre las imágenes del Holocausto y la dictadura argentina, la no televisación se debió a otras cuestiones más nimias y coyunturales?

La reserva en la emisión de la serie generaría una sucesión de consideraciones en torno a la política cultural del régimen. Nueva Presencia publicaría una columna de opinión de Luis Gregorich en la que cuestionaría la censura que regía durante el período, a la vez que deslizaba una fuerte crítica a la industria cultural que sostenía la dictadura. El objeto de la crítica serían los films en los que se destacaban la dupla de Alberto Olmedo y Jorge Porcel, que divulgaban una representación de las mujeres como objetos.

Sin embargo, un episodio posterior centró la discusión en el antisemitismo en Argentina y reintegró el debate sobre la serie, que posibilitó, a posteriori, su televisación. El 28 de octubre de 1980, durante la emisión del programa Videoshow, conducido por Enrique Llamas de Madariaga en Canal 9, fue entrevistado el ingeniero Jaime Rozenblum acerca de las características y la condición del judío en Argentina. El reportaje se centró en una supuesta conducta ambigua de los judíos en torno de su «lealtad» con Israel, su reticencia a asimilarse

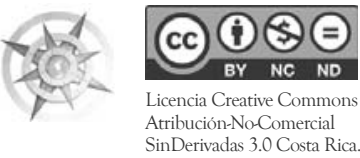

Los usos del pasado durante la última dictadura militar... 159 Emmanuel Nicolás Kaban • Laura Schenquer 
a la «sociedad nacional»y los recelos contra la «argentinidad» (Nueva Presencia, 31 de octubre de 1980). ${ }^{14}$

Si bien durante gran parte de ese año se sucedieron una serie de atentados y profanaciones de cementerios, la reacción frente a la difusión televisiva de argumentos considerados como antisemitas brindó al acontecimiento un lugar destacado en los posicionamientos y la movilización de la comunidad judía. Desde la DAIA, por ejemplo, se emitiría una solicitud condenando las «patrañas antisemitas» en momentos «en que la República realiza los más denodados esfuerzos por superar las secuelas sangrantes de las heridas dejadas por la violencia en recientes años aciagos» (Informativo DAIA, No. 98, noviembre de 1980: 5).

Como parte de su estrategia de intervención, la DAIA buscó pronunciamientos

14 Esta no fue la única ocasión en que una intervención de Enrique Llamas de Madariaga despertaría polémicas por sus declaraciones en torno a la poca lealtad de los judíos a la Argentina. Durante el desarrollo de la contienda bélica en las Islas Malvinas, el periodista se preguntó, durante una emisión radial, "por qué todas las colectividades se movilizaron menos la judía». Esta expresión, que por cierto no fue cierta, puso en escena, nuevamente, una serie de debates en torno a los modos de integración de la vida judía en Argentina (Kahan, E. (2014). Recuerdos que mienten un poco. Vida y memoria de la experiencia judía durante la última dictadura militar. Buenos Aires: Prometeo). oficiales que condenaran la actitud del periodista Llamas de Madariaga. La búsqueda de la condena oficial, según el testimonio de Gorenstein, radicó en que desde la comunidad judía «se consideraba que como la televisión se encontraba fiscalizada por el Estado, el programa no podía emitirse sin "previa aprobación de los organismos oficiales competentes"». (Informativo DAIA, No. 98, noviembre de 1980: 3).

La primera de ellas llegaría tras la reunión mantenida entre la delegación de la DAIA, encabezada por su presidente Mario Gorenstein, y el ministro del Interior, Álbano Harguindeguy. En aquella reunión, en la cual también se presentaron quejas por la profanación de tumbas en el cementerio judío de Liniers, el funcionario oficial emitió un comunicado en el que condenaba estas expresiones antisemitas por «estar reñidas con las más puras tradiciones de nuestra Nación» (Informativo DAIA, noviembre de 1980: 7).

A su vez, las acciones de la entidad se dirigieron a entrevistar también al secretario de Información Pública de la Presidencia, el general Llamas -hermano del periodista Enrique Llamas de Madariaga-, quien solicitó a la DAIA que sugiriera las medidas que consideraran más apropiadas para subsanar la situación. A partir de este intercambio se incorporaría a rabinos

160 Los usos del pasado durante la última dictadura militar... Emmanuel Nicolás Kaban • Laura Schenquer
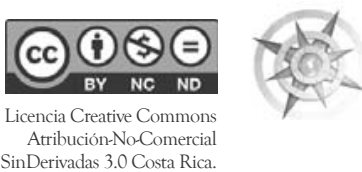
en los cierres de transmisión de los canales estatales -como lo hacían los sacerdotes católicos- y comenzarían a abrirse las gestiones para permitir la emisión de la serie televisiva Holocausto, que aún permanecía prohibida. Para los dirigentes de la entidad, la transmisión de la misma podría revertir la agitación confusionista que pretendía diluir la magnitud del exterminio de seis millones de judíos (Informativo DAIA N. 104).

Las negociaciones para la emisión de la serie, no obstante, no tendrían resultados inmediatos. Habría que esperar a finales de 1981, en el mes de diciembre, para que pudiera verse la serie Holocausto en el país. En la columna "De semana en semana" de Mundo Israelita se celebraría la emisión televisiva en Canal 9, pero advirtiendo, aún en el contexto dictatorial, que la serie, que contiene imágenes de tortura y fusilamientos, sería televisada «sin cortes», una forma de aludir a la censura.

Si bien la dirigencia de la comunidad judía saludaría la posibilidad de que esta miniserie fuera emitida en la televisión local, la presentación de la misma que realizó el periodista Horacio Carballal -ex subsecretario de Cultura del Gobierno de facto del general Lanusse- mereció cuestionamientos por parte de diversas voces del espectro judaico: se le recriminó que «durante la apretada explicación previa» y la posterior no se dijera nada sobre quiénes fueron las víctimas del Holocausto, los judíos, «escamoteando la memoria de las víctimas»:

Luego de puntualizar diversos aspectos referentes a lo que podríamos denominar la «ficha técnica» de la miniserie, el encargado por la Dirección de Canal 9 de pronunciar las palabras preliminares, hizo una serie de apreciaciones «explicativas» sobre la «producción y sus intérpretes» y dijo que las secuencias a difundirse enfocarían el «dolor de la familia Weiss». Con una extremada dosis de «asepsia» descriptiva, el comentarista citado evitó cuidadosamente subrayar el hondo carácter de testimonio del martirologio judío de este telefilme. Para él, todo el drama parece que se hubiera reducido a las «peripecias de la familia Weiss». ¿Acaso no sabe ese caballero que la «familia Weiss» solo conforma en el film un símbolo del infortunio sufrido por todo el pueblo judío? (Mundo Israelita, 19 de diciembre de 1981: 8).

Ni la lectura de Carballal ni la de los miembros del campo judío proponían entonces pensar al lager en la ficción como representación equiparable a la experiencia concentracionaria desplegada por el régimen dictatorial argentino.

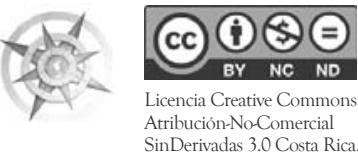

Los usos del pasado durante la última dictadura militar... 161 Emmanuel Nicolás Kaban • Laura Schenquer 
Esta perspectiva se encontraría, también, en las consideraciones de Leonardo Senkman, cuestionando, en primer término, cómo fue "vendida» publicitariamente la serie: "Lo que está en juego son las connotaciones hermenéuticas de lo que algunos quieren que se interprete como el Holocausto judío» (Nueva Presencia, 18 de diciembre de 1981: 10). La disquisición de Senkman -como la de Meyer en relación con el uso que Timerman hacía del Holocausto para referirse al caso argentino- ponía en consideración las limitaciones de la homologación de diversas experiencias:

La tentación humanista de interpretar el Holocausto judío, disuelve, hasta evaporizar sus peculiaridades incomparables, toda especificidad histórica y concreta de la tragedia del Holocausto. Porque querer equipararlo con el genocidio tremendo de otros pueblos, es empezar por bastardearlo. Y no porque los cadáveres judíos gaseados en Auschwitz sean más humanos que los millones de armenios, gitanos, polacos, ibos, negros o japoneses muertos en genocidios. La peculiaridad del Holocausto consistió en el inequívoco designio de los nazis de exterminar sistemáticamente hasta el último judío que viva sobre la faz de la tierra. El genocidio no alcanza a dar cuenta de la tragedia del Holocausto. No basta una maquinaria dictatorial, campos de concentración, violación de los derechos humanos y un Reich brutal que fusile a millones de hombres. Porque el Holocausto, además, sólo puede entenderse en su especificidad judía si se comprende que la «solución final del problema judío» era el exterminio total, solo para ese pueblo (...) La tentación humanista, en el fondo, también le hace el juego a la mala conciencia de los que niegan el Holocausto y a aquellos que no se plantean la pasividad y la falta de responsabilidad por el destino judío (Nueva Presencia, 18 de diciembre de 1981: 10).

\section{El Holocausto y la dictadura duran- te los primeros tramos del restableci- miento democrático}

Entre 1983 y 1984, en un clima diferente al de censura de los años previos, el rabino Meyer justificó su rechazo a toda construcción ejemplar del Holocausto, y, en cambio, explicitó los motivos que lo llevaban a reclamar su uso literal ${ }^{15}$ : «No creo que el

15 Según Todorov, en su texto Los abusos de la memoria (2002). Buenos Aires: Paidós, el Holocausto puede ser recordado de manera literal, lo que implica su recuperación intransitiva en la que se aduce que la preservación de su verdad depende de no ir más allá del acontecimiento en sí mismo; o bien puede ser recuperado en forma ejemplar que permite, sin negar su singularidad, utilizarlo como

162 Los usos del pasado durante la última dictadura militar... Emmanuel Nicolás Kaban • Laura Schenquer
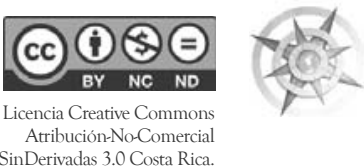
Holocausto de los 6.000.000 lo podamos comparar con lo que paso acá. El Holocausto fue un hecho espantosamente único en el que los judíos fueron matados por profesar una fe» ( $\mathrm{Paz}$ y Justicia, 5 de octubre de 1983: 21).

Por ese tipo de declaraciones es que no resulta llamativa la discusión entre Meyer y el periodista Herman Schiller, director de Nueva Presencia, cuando compartían la dirección del Movimiento Judío por los Derechos Humanos (MJDH) creado en octubre de 1983 para marchar en repudio a la Ley de Autoamnistía Militar. En el marco de la organización del acto por el 41. ${ }^{\circ}$ Aniversario del Levantamiento del Gueto de Varsovia, en 1984, recuerda Moshé Wainstein, miembro del MJDH, que hubo controversias cuando Schiller y otros integrantes del movimiento manifestaron que querían darle al acto en memoria del Holocausto un cariz que sirviese para reflejar la situación represiva recientemente clausurada en Argentina. Querían que el movimiento fuese el portador del mensaje de comparación de ambos genocidios. ${ }^{16}$

manifestación o modelo para comprender otras situaciones históricas, tales como la dictadura militar argentina.

16 Sobre esta disputa ver los artículos publicados por Moshé Wainstein y Fernando Sokolowicz en Nueva Presencia el 11 de mayo de 1984 (p. 6) y el 16 de
Pese a las tensiones al interior del $\mathrm{MJDH}$, el acto en conmemoración al Levantamiento del Gueto de Varsovia fue realizado el 25 abril de 1984 al pie del Obelisco. No solo el lema de la convocatoria mostraba la aceptación de la comparación o del uso ejemplar del tropo - «Ni olvido ni perdón. Nunca más un Holocausto»-, sino que el propio Marshall Meyer, desde el escenario y como uno de los oradores del acto, accedió a establecer vínculos entre la dictadura nazi y la argentina pese a su oposición previa. Su discurso subrayó el deber de memoria que caracterizó a este período de transición y vuelta a la democracia (Goldstein, 2006). El Holocausto comenzó a ser propagado más allá de la experiencia judía como símbolo

diciembre de 1983 (p. 31). Asimismo, cabe destacar que el sentido del acto de 1983 no fue la única diferencia entre Meyer y Schiller. Meyer -cercano al presidente Alfonsín y miembro de la CONADEP (Comisión Nacional sobre la Desaparición de Personas en Argentina) - evitó criticar al Gobierno cuando este tomó la decisión de que los militares debían juzgarse a sí mismos o bien «auto-depurarse». En ese contexto, Schiller increpó al rabino: "QQué hubieses opinado vos si a los criminales de guerra nazis los hubieran juzgado los propios alemanes?» (Nueva Presencia, 17 de febrero de 1984, pp. 1 y 3).

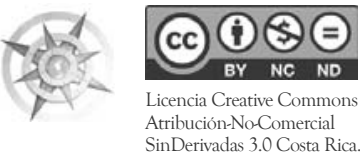

Los usos del pasado durante la última dictadura militar... 163 Emmanuel Nicolás Kaban • Laura Schenquer 
de lucha contra el olvido, vinculado a la no repetición y en virtud de la demanda de justicia:

Estamos reunidos aquí esta noche porque tenemos memoria. La memoria es un puente vital en donde se fusionan pasado, presente y futuro (...) En la Argentina, hemos vivido nuestra propia larga noche de horror y crimen en la cual nuestros compatriotas se mantuvieron al margen, callados... en un silencio dictado por el miedo, o la comodidad, o la incredulidad, o la falta de solidaridad humana, o la falta de compasión y sensibilidad.

Cuando la comunidad europea se negó a tomar en serio a Hitler, o la persecución a los judíos, redactó su propia sentencia de muerte. Toda Europa debió pagar el precio por esta falta de respuesta adecuada. Los argentinos hemos vivido un mini-holocausto [cursivas añadidas] durante los años de la dictadura militar. Nuestra tierra todavía está empapada de sangre inocente. El pueblo argentino exige justicia (Nueva Presencia, 1 de junio de 1984, pp. 2 y 6).

Si bien es cierto que se establecían puentes entre un acontecimiento y el otro, no deja de llamar la atención el término mini-Holocausto, que refiere al tropos, pero no en su completitud, sino como una repetición parcial, disminuida, tal vez en función de la comparación numérica entre las víctimas, y que podría ser pensado como el argumento que hacía posible la defensa de la particularidad del Holocausto, de su in-transferencia y de su unicidad. Lo que efectivamente se explicita como una relación entre un acontecimiento y el otro, es el rol ya no de las víctimas, sino de los testigos voluntarios/involuntarios, la población común y corriente cuyas actitudes múltiples, siempre negativas, varían en una gama que va desde el miedo hasta la falta de sensibilidad. Ese es el punto que resuena en el discurso de Meyer y que evidencia que en ambos acontecimientos hubo argentinos y alemanes que fueron pasivos ante el horror. A ellos, el rabino se dirige demandándoles que exijan justicia, que traduzcan las consecuencias del horror nazi en una lección.

\section{Conclusión}

Este trabajo nos muestra el modo en que emergió tempranamente en Argentina el Holocausto como universo de significados que fue utilizado para interpelar la propia experiencia dictatorial atravesada en el país. Desde el testimonio de Timerman hasta los debates en los primeros tramos de la recuperación democrática, el genocidio nazi constituyó para algunos sectores del campo judío local

164 Los usos del pasado durante la última dictadura militar... Emmanuel Nicolás Kaban • Laura Schenquer
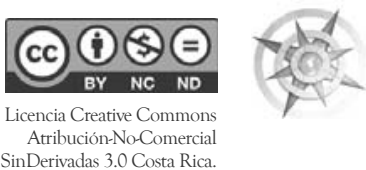
un acontecimiento rememorado para denunciar el modo en que operaba la dictadura militar.

Este hallazgo nos permite suspender la afirmación de que solo recientemente ingresamos a la «era en la que el Holocausto se ha convertido en el tropos universal del trauma histórico» (Huyssen, 2007: 17). Nuestro trabajo da cuenta de que en los setentas hubo voces dispuestas a proponer el Holocausto como horizonte de identificación del trauma que estaban atravesando.

Pero estas narrativas dispuestas a homologar la experiencia local con el Holocausto no fueron las más aceptadas o extendidas e incluso generaron controversias entre los miembros de la comunidad judía. Había que esperar por lo menos una década para que el Holocausto fuera socialmente aceptado como símbolo de las tragedias en diferentes territorios. ${ }^{17}$

Las narrativas que admiten un uso ejemplar del Holocausto corren el riesgo de silenciar las particularidades

17 Fue en el marco de las transiciones hacia las democracias que en los países del Cono Sur fue importado el discurso sobre el Holocausto, menos como acontecimiento y más como metáfora utilizada para comparar lo sucedido en estos países. Ver la globalización del Holocausto en Los trabajos de la memoria (2002). Madrid: Siglo Veintiuno de España Editores, de Elizabeth Jelin. de los diversos acontecimientos con los que este es comparado. Tras su liberación Timerman buscó multiplicar las voces que reconocieran la experiencia de los judíos argentinos durante la dictadura. A pesar de la desazón que debió causarle el bajo impacto que tuvo la visita de Elie Wiesel (quien en 1979 no hizo ninguna referencia al Holocausto argentino), volvió a contactarlo para que ambos escribiesen un libro con sus testimonios como sobrevivientes de regímenes totalitarios. Este proyecto fracasaría. Timerman no dudaría entonces en acusar al reconocido sobreviviente del Holocausto, en una misiva remitida al rabino Marshall Meyer, por su negativa a vincular una y otra experiencia:

Varias veces me he preguntado por el libro que hicimos juntos con Elie. Estuvimos juntos en East Hampton, en casa de uno de esos millonarios que Elie gusta halagar. Trabajamos muy intensamente diez días. Salimos de East Hamptom en coche. Elie llevaba mi parte del libro pero no me dio copia de la parte de él. Simplemente me la leyó verbalmente, y dijo que quería hacer unas correcciones (...) Bob Bernstein [el editor] llamó varias veces a nuestro representante para decirle que deseaba editar el libro y estaba dispuesto a subir cualquier oferta de Simon $\&$ Schuster, o quien fuera. Al bajar del coche, con mi valija y mi

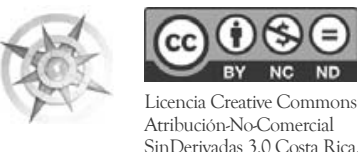

Los usos del pasado durante la última dictadura militar... 165 Emmanuel Nicolás Kaban • Laura Schenquer 
máquina de escribir, le dije a Elie: «Hasta mañana». Y nunca más lo vi (...) Como además es muy hábil, nunca me dejó su copia del libro. El asunto me da mucho asco. Cuando el asco se me pase, revisaré las copias de lo que yo escribí y te mandaré un ejemplar. iAh, querido Rabino!, cuántas cosas, y cuánto dinero, en nombre del Holocausto (Timerman, 29 de junio de 1980).

La posibilidad de que una personalidad reconocida en el campo de los sobrevivientes del genocidio nazi legitimara el testimonio y la posición de Jacobo Timerman tensionó uno de los primeros momentos en que el Holocausto emergería como acontecimiento de interpretación y denuncia de la propia experiencia. No obstante, más allá de este traspié, el testimonio de Timerman se convertiría en el canon de interpretación de la dictadura militar y del particular trato dado a los judíos durante aquellos años. Las polémicas suscitadas en los primeros tramos de la recuperación democrática son ilustrativos: allí el tropo de la víctima se constituye en un discurso legitimador de las prácticas de memoria y reconocimiento de la política persecutoria del régimen dictatorial.

Desde entonces, podríamos hipotetizar, el tropo del Holocausto ha servido para legitimar distintas narrativas: la de aquellos que buscaron homologar la dimensión trágica de una experiencia para poder inscribirse en el derrotero del trauma histórico y la de otros que inscribieron su condición de víctimas singulares del proceso histórico.

\section{Referencias bibliográficas}

\section{Prensa periódica, boletines y archivos}

Acerca de un polémico afiche. (11 de mayo, 1984). Nueva Presencia, p.6.

Anti-Semitism called price of Jewish life in Argentina (3 de julio, 1981). The Miami Herald, pp.1 y 14 .

Argentina's Fighting Rabbi (febrero, 1983). Hadassah, pp. 7-9.

Delegación de Asociaciones Israelitas Argentinas (5 de junio, 1977). El titular de la DAIA denunció a los antisemitas que intentan enturbiar el actual proceso. Informativo DAIA, N. ${ }^{\circ}$ 92, pp.16-17.

Delegación de Asociaciones Israelitas Argentinas (5 de junio 1977). El ministro del Interior recibió a una delegación de la DAIA Informativo DAIA, № 92, p.6

Delegación de Asociaciones Israelitas Argentinas (noviembre, 1980). Solicitada de la DAIA contra provocación antisemita en Videoshow. Informativo DAIA, N. ○98. p. 8.

Delegación de Asociaciones Israelitas Argentinas (noviembre, 1980). La respuesta judía a la provocación. Informativo DAIA, N. ${ }^{\circ} 98: 3-4$.

Delegación de Asociaciones Israelitas Argentinas (noviembre, 1980). Los hechos antisemitas están reñidos con el sentir argentino. Informativo DAIA, $\mathrm{N}^{\circ} 98$, pp 5-7.

166 Los usos del pasado durante la última dictadura militar... Emmanuel Nicolás Kaban • Laura Schenquer
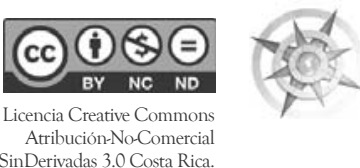
Delegación de Asociaciones Israelitas Argen-

Dirigentes comunitarios mantuvieron un diálogo cordial con Kissinger. (1 de junio, 1979). Mundo Israelita. p.15.

El fantasma de Dreyfus (10 de diciembre, 1977). Nueva Presencia, p. 1.

Elie Wiesel on what makes a Jewish writer tick (1 de septiembre, 1979). Buenos Aires Herald, p. 9.

Genocidio humano u Holocausto judío (18 de diciembre, 1981). Nueva Presencia, p. 10.

Graetz, H. (1979). Dilemas del ser judío. Emanu El, año 1, N. 1, 10-12.

Gregorich, L. (30 de noviembre, 1979). Una censura que fomenta la obscenidad. Nueva Presencia, p. 10.

Los judíos (junio, 1977). Carta Política, pp 10-14

Los judíos argentinos y los derechos humanos (5 de octubre, 1983). Paz y Justicia, pp. 20-25.

Marshall Meyer escogió luchar por la vida (1 de junio, 1984). Nueva Presencia, pp. 2 y 6.

Meyer, N. (s/fe.). Entrevista realizada por Gabriela Lotersztain. [DVD 1], no 1 , s/f.e. [1996-2006], IDES.

Nobel prize-winner claims disappearance. (5 de septiembre, 1979), Buenos Aires Herald 5. p.1.

Otra vez el olvido (19 de diciembre, 1981). Mundo Israelita, p.8.

Polak, C. (24 de agosto, 1979). ¿Quién le teme a «Holocausto» en nuestro país? Nueva Presencia, p. 5

¿Por qué la TV argentina no emite Holocausto? (13 de febrero, 1981). Nueva Presencia, p.2.

Texto completo del diálogo entre Llamas de Madariaga y J. Rozenblum (31 de octubre, 1980). Nueva Presencia, pp. 8-12.

Timerman, J. (29 de junio, 1980). Carta de J.T. a M.M. Archivo del SRL.
Voces de aliento, críticas y sugerencias: Derechos Humanos y Racismo. (16 de diciembre, 1983). Nueva Presencia, p.31

Wainstein, M. (27 de noviembre, 1981). Detenidos- Desaparecidos: un nuevo hito en la ardorosa polémica interna desatada en la comunidad judía. Nueva Presencia, pp. 10-11 y 18.

Wiesel, E. (20 de julio, 1979). Direct translation of suggestions made by Jacobo Timerman on Friday, 20th of July 1979. Archivo SRL, Colección Marshall Meyer. Caja 2.

\section{Libros y revistas}

Goldstein, Y. (2006). El judaísmo argentino de fin de siglo XX: del olvido a la recuperación de la memoria colectiva. En A. Huberman y A. Meter (eds.), Memoria y representación. Configuraciones culturales y literarias en el imaginario judio latinoamericano (pp. 41-63). Rosario: Beatriz Viterbo Editora.

Huyssen, A. (2007). En busca del futuro perdido. Cultura y memoria en tiempos de globalización. Buenos Aires: Fondo de Cultura Económica.

Kahan, E.(2011). Discursos y representaciones en conflicto sobre la actuación de la comunidad judía durante la última dictadura militar: análisis de los Informes sobre 'los detenidos-desparecidos de origen judío' 1984-2007. En Kahan, E., Schenquer, L., Setton, D. y Dujovne, A. (comps.). Marginados y consagrados. Nuevos estudios sobre la vida judía en Argentina. Buenos Aires: Edit. Lumiere.

. E. (2014). Recuerdos que mienten un poco. Vida y memoria de la experiencia judía durante la última dictadura militar. Buenos Aires: Prometeo.

Klich, I. (1986). Política comunitaria durante las juntas militares

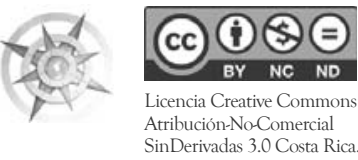

Los usos del pasado durante la última dictadura militar... 167 Emmanuel Nicolás Kaban • Laura Schenquer 
argentinas: la DAIA durante el proceso de reorganización nacional. En L. Senkman (comp.), El antisemitismo en Argentina. [pp. 274-309].. Buenos Aires: CEAL.

Lotersztain, Gabriela. (2008). Los judios bajo el terror. Argentina 1976-1983, Buenos Aires: Editorial Ejercitar la Memoria. Mochkofsky, Graciela. (2003). Timerman. El periodista que quiso ser parte del poder (1923-1999), Buenos Aires: Edit. Sudamericana.
Rein, Raanan. (2011). ¿Judís-argentinos o argentinos-judios? Identidad, Etnicidad y diáspora. Buenos Aires: Editorial Lumiere.

Saborido, J. (2004). El antisemitismo en la Historia argentina reciente: la revista Cabildo y la conspiración judía. Revista Complutense de Historia de América, 30, pp. 209-223

Timerman, J. (1982). El caso Camps, punto final [Preso sin nombre, celda sin número]. Buenos Aires: Editorial El Cid.

Todorov, Tzvetan. (2002). Los abusos de la memoria. Buenos Aires: Paidós.

168 Los usos del pasado durante la última dictadura militar... Emmanuel Nicolás Kaban • Laura Schenquer
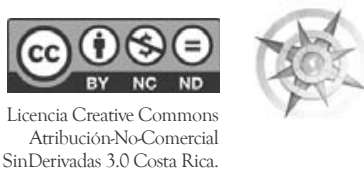